Straßer, Daniel; Montenegro, Héctor; Blechschmidt, Lisa; Liesch, Tanja; Goldscheider, Nico

\title{
Multi-tracer approach to characterize hydraulically-induced sulfate rock dissolution processes below a weir lock
}

Originalveröffentlichung / Original Publication:

https://doi.org/10.1080/23249676.2016.1172992

Verfügbar unter / Available at:

https://hdl.handle.net/20.500.11970/104562

Vorgeschlagene Zitierweise / Suggested citation:

Straßer, Daniel; Montenegro, Héctor; Blechschmidt, Lisa; Liesch, Tanja; Goldscheider, Nico (2016):

Multi-tracer approach to characterize hydraulically-induced sulfate rock dissolution processes below a weir lock. In: Journal of Applied Water Engineering and Research 5 (2). S. 1-16. 


\title{
Erstveröffentlichung in Journal of Applied Water Engineering and
}

Research 20 April 2016 (2016), S. 1-16.

Für eine korrekte Zitierbarkeit ist die Seitennummerierung

der Originalveröffentlichung für jede Seite kenntlich gemacht.

\section{Multi-tracer approach to characterize hydraulically induced sulfate rock dissolution processes below a weir lock}

\author{
Daniel Strassera ${ }^{a}$, Héctor Montenegroa, Lisa Blechschmidtb, Tanja Liesch ${ }^{\mathrm{b}}$ and Nico Goldscheider \\ a Department of Geotechnical Engineering, Federal Waterways Engineering and Research Institute (BAW), Karlsruhe, \\ Germany; \\ b Institute of Applied Geosciences, Division of Hydrogeology, Karlsruhe Institute of Technology (KIT), Karlsruhe, Germany \\ *Corresponding author. Email: daniel.strasser@baw.de
}

Numerous damages at structures and failures of dams can be ascribed to solution processes and attendant subsidence. Leaching in gypsum-bearing layers of the Middle Triassic has induced subsidence underneath the structure of the weir Hessigheim, River Neckar. The goals of this study were to gain a better understanding of the prevailing groundwater flow processes as well as the interaction between surface water and groundwater in the area of the weir lock and to verify the success of former remediation measures. In order to attain these objectives a combined groundwater and surface water tracer test in combination with hydraulic borehole tests were performed. In addition, a study of the dissolved sulfate distribution was carried out using sampling data from 1987 to 2013. Based on the results of these methods a strongly heterogeneous aquifer with main runoff occurring in few major flow paths could be characterized. Former remediation measures showed to be successful.

Keywords: karst; subsidence; sulfate leaching; tracer test

\section{Introduction}

Dissolvable bedrock often poses significant challenges to planners of hydraulic structures. In the past, numerous damages at structures and failures of dams, barrages and weirs were attributed to subsurface dissolution processes (James 1992; Klinchouk \& Andrejchuk 1996a; Ford and Williams 2007). Worldwide, vast areas consist of rock formations which can develop karst (Klinchouk \& Andrejchuk 1996b), whereby difficulties in construction projects are sometimes unavoidable. Due to the relatively high solubility of sulfates and carbonates, compared to other minerals, topography changes, such as subsurface erosion or subsidence in karst areas, are not uncommon (Cooper 1986). These kinds of transformations occur in, geologically speaking, very short periods of time (Jeschke 2002) and are sometimes intensified by human intervention in natural geohydraulic conditions. Caused by the higher solubility of sulfate in water, compared to carbonate minerals, solution processes often occur more rapidly in sulfate rocks (Dreybrodt et al. 2002). However, problems with both rock types in combination with construction works have occurred in the past 


\section{Autorenfassung}

Strasser, Montenegro, Blechschmidt, Liesch, Goldscheider: Multi-tracer approach to characterize hydraulically induced sulfate rock dissolution processes below a weir lock, 2016

(Milanovic 2000). Hydraulic structures often produce strong alterations in the natural interactions between surface water and groundwater, and therefore modify the geohydraulic conditions in adjacent aquifers. Steeper hydraulic gradients, leading to a higher groundwater flow rate, can occur. This process results in higher solution rates in the subsurface and higher subsidence, consequently. Lienhart (2013) as well as Romanov et al. (2006) discuss challenges and problems with dam sites built on carbonate rocks and associated solution processes. Even more literature focuses on similar challenges in sulfate rocks, for example, Saddam Dam/Iraq (Mesny 2004), a dam in Huesca Province/Spain (Gutierrez et al. 2003) and the Birs weir/Switzerland (Hiller et al. 2012). The subject of this study, the weir lock Hessigheim at Neckar River, is also situated in a sulfate-bearing geological environment.

Along the middle reach of the Neckar River in the southwestern part of Germany a total of 15 weirs produce a navigable water level independent of the seasonally fluctuating water runoff. Some of these structures are founded in easily dissolvable bedrock and are now around 60 years in function and in need of restoration. Particularly, the weir lock Hessigheim has been subjected to several expansive restoration measures in the past. Leaching in gypsumbearing layers of the Middle Triassic (Middle Muschelkalk) caused subsidence, which in turn results in damages of the structure. In recent decades, drilling campaigns were conducted to obtain information about the progress of the leaching process. Remediation actions, such as the injection of cement suspension and installation of sheet piling, led to a temporary deceleration of the settlement and thus to an improvement in the structural situation. Nevertheless, it still comes to subsidence in the immediate vicinity of

Strasser, Montenegro, Blechschmidt, Liesch, Goldscheider: Multi-tracer
approach to characterize hydraulically induced sulfate rock
dissolution processes below a weir lock.

the construction, producing tensile and shear stress in the structure.

To gain a better understanding of the prevailing groundwater flow processes and the interaction between surface water and groundwater in the area of the weir lock, extensive hydrogeological investigations were carried out at the site Hessigheim. The increase of the hydraulic gradient is the driving force behind the dissolution processes in the subsurface of the site. Detailed knowledge of the hydraulic connections amongst the aquifer system and the river, as well as the hydraulic characteristics of the karst aquifer system on which the concrete structure of the weir and the ship lock are founded, is needed to develop strategies for a sustainable remediation concept. The aim of the present study was to obtain a better understanding of the complex geohydraulic conditions in the area of the weir lock as an essential base for future maintenance measures. Hydraulic connections, for example, preferential flow channels, as well as zones which currently have the highest sulfate leaching rate, should be identified. In addition, the success or the effect of former hydraulic remedi- 


\section{Autorenfassung}

Strasser, Montenegro, Blechschmidt, Liesch, Goldscheider: Multi-tracer approach to characterize hydraulically induced sulfate rock dissolution processes below a weir lock, 2016

ation measures should be verified, respectively. These objectives were addressed by a series of hydraulic tests, hydrogeochemical studies and a combined ground- and surface-water tracer test.

\section{Area under investigation}

\subsection{Weir lock Hessigheim, Neckar River}

The weir lock Hessigheim is located $15 \mathrm{~km}$ south of the city of Heilbronn (BadenWürttemberg/Germany) on a Neckar River meander (Figure 1). The landscape is characterized by steep undercut banks and moderately steep slip-off slopes of the river.

After two years of construction, the weir and the eastern lock chamber were taken in operation in the summer of 1952. In 1961, a second lock chamber was added (Figure 2(a)). The weir permanently induces a head difference of about $6.2 \mathrm{~m}$

Upstream and downstream, the lock area is separated from the river flow by a pier. At low water level, the stream is completely used for power generation. In order to regulate the waterlevel, three weir segment-gates can be opened or closed according to the flow conditions of the Neckar. The concrete base plate of the weir is founded in the Neckar gravel and fixed with deep sheet piling (Figure 2(b)).

The foundations of the lock gates were fixed with piles and sheet piling reaching the level of the residual clay (Figure 2(c)). The flat foundations of the weir and the power plant on the eastern bank lie above the Neckar gravel. Sheet piles surrounding the power plant and the weir foundations reaching into the lower aquifer (Upper Clay-Anhydrite-Formation) were added because of major settlements, particularly in the machine hall of the power plant (Franzius 1990). Copious remediation measures have already been accomplished in the weir lock's 60 years' operation time to improve the load-bearing properties of the ground (Wittke 1998). Most of these actions concentrated on filling cavities in the ground. In addition, a grout curtain was injected between 1986 and 1998 encompassing the entire structure (Figure 2(d)), to divert the 


\section{Autorenfassung}

Strasser, Montenegro, Blechschmidt, Liesch, Goldscheider: Multi-tracer approach to characterize hydraulically induced sulfate rock dissolution processes below a weir lock, 2016

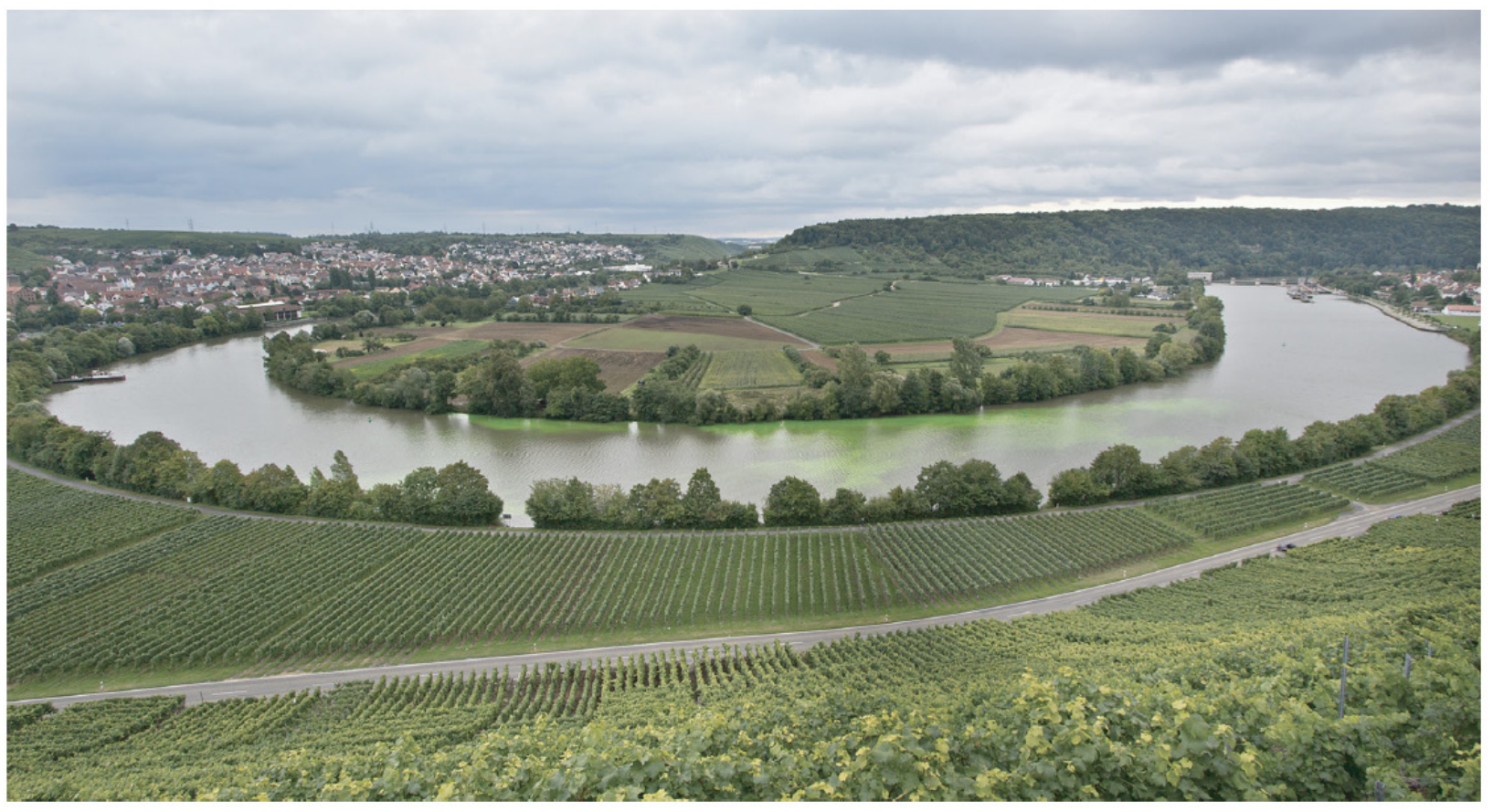

Figure 1. The Neckar River meander upstream of the weir lock Hessigheim. The green plumes are the result of the injection of Uranine during the tracer test.

Strasser, Montenegro, Blechschmidt, Liesch, Goldscheider: Multi-tracer approach to characterize hydraulically induced sulfate rock dissolution processes below a weir lock. Journal of Applied Water Engineering and Research 20 April 2016 (2016), S. 1-16. 


\section{Autorenfassung}

Strasser, Montenegro, Blechschmidt, Liesch, Goldscheider: Multi-tracer approach to characterize hydraulically induced sulfate rock dissolution processes below a weir lock, 2016

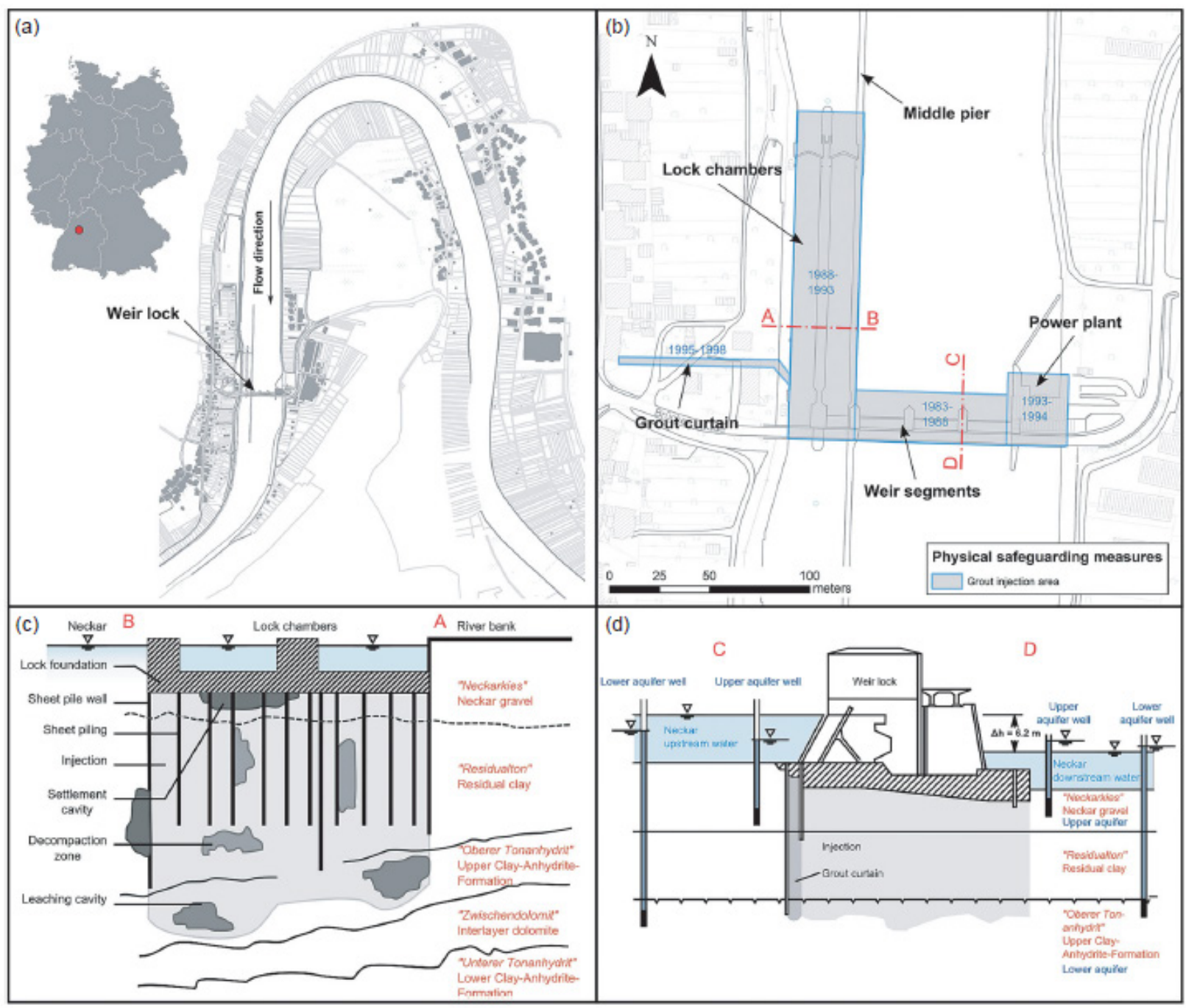

Figure 2. (a) Overview of the investigation area; (b) site plan of the weir lock Hessigheim including the position of the cross-sections; the building consists of a two-chamber lock system, a weir and a power plant; (c) and (d) cross-sections of the lock chambers and the weir.

local groundwater flow and so prevent the weir lock from concentrated underflow.

In spite of these efforts, subsidence could not be stopped and continues to affect the structure. Even with the groundwater flow-regulating measures, the situation could not be improved sufficiently and sustainably. Thus it is still crucial to gain a better understanding of the prevailing groundwater flow pattern and the coupled hydraulic, geochemical and geomechanical processes in the area around the weir lock. 


\subsection{Geology and hydrogeology}

The Neckar basin in total is formed by rocks of the Middle Triassic (Upper Muschelkalk). The upper parts of the Muschelkalk formation have been eroded by the Neckar River in the area of Hessigheim. Here, the rocks of the Middle Muschelkalk crop out (Brunner et al. 1994). In the valley, these are superimposed by river gravel and Pleistocene alluvial fans. A simplified geological crosssection through the weir lock is shown in Figure 2(c). The Heilbronn-Formation, belonging to the Middle Muschelkalk, is present in the weir lock area. This geological formation consists of evaporitic rocks, anhydrite or gypsum and salt. The dominant layer of the Clay- Anhydrite-Formation consists of anhydrite, which has been transformed into gypsum in most parts of the area, and interlayers of clay and dolomite. It can be subdivided in a depth of about $30 \mathrm{~m}$ into the Upper and Lower Clay-Anhydrite-Formation by a distinctive, a few meters thick, dolomite layer. The Upper Clay-Anhydrite-Formation consists of 87-99\% gypsum and the Lower Clay-Anhydrite-Formation averages only 67\% (Wittke 1998). Vast areas of the Upper Clay-Anhydrite-Formation are highly karstified. Some of the cavities were later filled with Neckar gravel or rock debris by collapse and sedimentation. In most

Strasser, Montenegro, Blechschmidt, Liesch, Goldscheider: Multi-tracer approach to characterize hydraulically induced sulfate rock dissolution processes below a weir lock. Journal of Applied Water Engineering and Research 20 April 2016 (2016), S. 1-16.

parts, the upper few meters of the Upper Clay-Anhydrite-Formation have been weathered to residual clay (Wittke 1998). This residual clay consists of cohesive solution residues of the Upper ClayAnhydrite-Formation with soft to stiff consistency. The interlayer dolomite acts as a natural barrier against the formation of cavities and erosion processes in the Lower Clay-Anhydrite-Formation. It is viewed as karst-resistive due to an average gypsum percentage of $21 \%$. Based on current research, leaching below the interlayer dolomite will, however, continue for much longer (Wittke 1998).

The subsurface can be subdivided into two aquifers separated by an aquitard. The upper aquifer is located in the Neckar gravel down to a depth of about $10 \mathrm{~m}$ below the river bed. It is in direct hydraulic contact with the adjacent surface water; however, upstream of the dam, the upper aquifer is presumably partially clogged.Groundwater levels measured in the upper aquifer differ just slightly from the river's water levels. At high river discharge rates, the heads in the upper aquifer show a significant increase. Upstream of the weir lock, influent flow conditions prevail; Figure 3. Head distribution based on a preliminary FE groundwaterflow analyses to understand the impact of grouting campaigns on the hydraulic conductivity below the weir structure (modified after Bethge 2013). Results of the hydraulic borehole investigations. the surface water infiltrates into the upper Quaternary gravel aquifer. Downstream, the measured water-level is higher for the groundwater compared to the river stage, which indicates effluent conditions. 


\section{Autorenfassung}

Strasser, Montenegro, Blechschmidt, Liesch, Goldscheider: Multi-tracer approach to characterize hydraulically induced sulfate rock dissolution processes below a weir lock, 2016

The upper aquifer is underlain and hydraulically separated from the Upper Clay-AnhydriteFormation by a layer of the residual clay. This cohesive sediment has a much lower hydraulic conductivity $(1 \times 10-9 \mathrm{~m} / \mathrm{s})$ than the Neckar gravel $(1 \times 10-2 \mathrm{~m} / \mathrm{s})$ and thus provides an aquitard between the two aquifers (Wittke 1998).

The Upper Clay-Anhydrite-Formation forms the lower aquifer from about 17 to $30 \mathrm{~m}$ below the river bed surface. Using water pressure tests (WD-tests), an average hydraulic conductivity of $1 \times 10-6-1 \times 10-5 \mathrm{~m} / \mathrm{s}$ was measured in leached and sound rock, respectively (Wittke 1998). The aquifer is confined, the hydraulic potential distribution of upper and lower aquifers differ only marginally. Areas with interruptive structures, such as joints, could act as hydraulic connection linking the upper with the lower aquifer. The groundwater isolines of the lower aquifer (Upper Clay-Anhydrite-Formation), based on a numerical simulation (Bethge 2013), are presented in Figure 3. The shut-off effect of the weir building provokes a rise of the hydraulic head of groundwater upstream the weir lock and an accompanying fall of the heads downstream the building, thus causing potential differences and subsequently an increased groundwaterflow through the western and the eastern banks of the river.

\section{Methods}

\subsection{Hydraulic borehole tests}

\subsubsection{General}

Hydraulic borehole tests can be used to determine the transmissivity or the hydraulic conductivity of the subsurface. The approach is based on a head variation in the borehole and the thereby induced compensating response of the aquifer. In this study, slug-injection tests and pumping tests were performed in several wells in the area of the weir lock Hessigheim (Figure 3). The filter screens of all these monitoring wells are located in the area of the lower aquifer. 


\section{Autorenfassung}

Strasser, Montenegro, Blechschmidt, Liesch, Goldscheider: Multi-tracer approach to characterize hydraulically induced sulfate rock dissolution processes below a weir lock, 2016

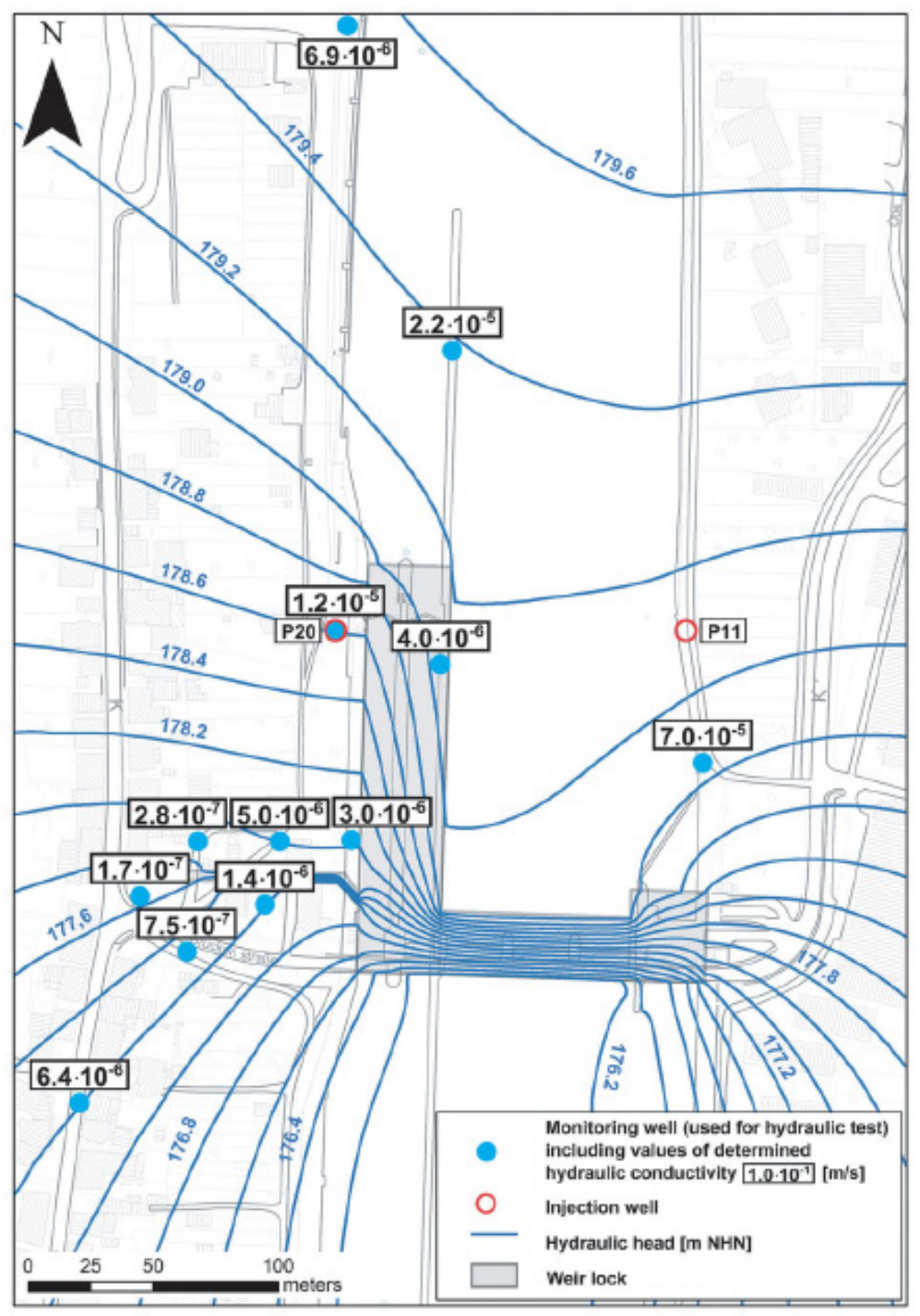

Figure 3. Head distribution based on a preliminary FE groundwater flow analyses to understand the impact of grouting campaigns on the hydraulic conductivity below the weir structure (modified after Bethge 2013). Results of the hydraulic borehole investigations.

\subsubsection{Slug-injection and pumping tests}

Slug-injection tests were performed at nine wells within the investigation area. For this purpose, $24 \mathrm{~L}$ of water were added to each well, resulting in an instantaneous rise of the head in the well between 2 and $6 \mathrm{~m}$, depending on the diameter of the respective testing well. The abrupt rise of the head inside the pipe generated a flow of water through he length of the filter screen until equilibrating toward the initial state. In the course of this study, the analytical approach of Hvorslev (1951) was applied to determine the hydraulic transmissivity. Similar to slug-injection 
Strasser, Montenegro, Blechschmidt, Liesch, Goldscheider: Multi-tracer approach to characterize hydraulically induced sulfate rock dissolution processes below a weir lock. Journal of Applied Water Engineering and Research 20 April 2016 (2016), S. 1-16.

tests, pumping tests are based on local variations of the groundwater potential (Kruseman \& de Ridder 2000). The approach of Theis (1935) was applied in this study, assuming confined geohydraulic flow conditions. In the course of field work in Hessigheim, pumping tests were performed at three wells with a pumping rate of about $0.25 \mathrm{~L} / \mathrm{s}$ until an equilibrium state was reached. The time and the change in pressure during the drawdown phase as well as the recovery phase were recorded and evaluated.

\subsubsection{Borehole dilution tests}

Borehole dilution tests use repeated fluid column profiling after establishment of an initial uniform tracer concentration (e.g. $\mathrm{NaCl}$ ) to monitor the rate at which ambient groundwater moves into a borehole. Application of the dilution technique in a monitoring well makes it possible to estimate the horizontal Darcy velocity of groundwater in the aquifer surrounding the borehole (Pitrak et al. 2007). The change in tracer concentration is a function of the Darcy velocity and can be described as follows:

$$
\ln \left(c_{i}\right)=-\left(\frac{2 \cdot v_{a}}{\pi \cdot r}\right) t_{i}+\ln \left(c_{1}\right)
$$

where $c_{i}[g / L]$ is the tracer concentration at time $t_{i}[s]$ after injection, $c_{1}[g / L]$ is the concentration of the tracer directly after injection, $\mathrm{r}[\mathrm{m}]$ is the borehole radius and $\mathrm{v}_{\mathrm{a}}[\mathrm{m} / \mathrm{s}]$ the apparent Darcy velocity, which has to be corrected to get the Darcy velocity by dividing it by a drainage coefficient, which is widely accepted to be about 2 (Pitrak et al. 2007).

These investigations were carried out in the potential tracer injection wells (P11, P20; cf. Figure 3) to determine vertical heterogeneity and especially natural horizontal Darcy velocities.

\subsection{Analysis of the sulfate content}

\subsubsection{General}

The sulfate content of groundwater can be used as a natural tracer bearing information about the flow conditions in the subsurface as well as water-rock interactions. The sulfate concentration in groundwater mainly depends on three factors (Käss 2004):

- the presence of gypsum-bearing rocks,

- the groundwater residence time and 


\section{Autorenfassung}

Strasser, Montenegro, Blechschmidt, Liesch, Goldscheider: Multi-tracer approach to characterize hydraulically induced sulfate rock dissolution processes below a weir lock, 2016

- the degree of mineralization of water inflows.

A high sulfate content possibly indicates low water flow rates, allowing a longer contact with the adjacent sulfate-bearing rocks and thereby increasing the concentration of dissolved sulfate. In extreme cases, when the hydraulic gradient is very low and the dissolved sulfate ions are transported slowly or not at all, complete sulfate saturation may be reached. Approaching the saturated state, the leaching process slows down progressively. Areas with high hydraulic gradients, which have a considerable influx of fresh water and short residence times, usually exhibit lower concentrations of dissolved sulfate and an increased leaching rate. In extreme cases, almost no soluble sulfate rock remains after leaching.

\subsubsection{Groundwater sampling}

The groundwater was sampled in 30 wells in the vicinity of the weir lock in both the upper and the lower aquifers (Figure 4(b)). The sampling was carried out by pumping. A previous sulfate sampling campaign was conducted by Wittke (1987). For evaluation of the changes since then the results of 1987 were compared to the results of the current campaign.

\subsubsection{Surface water sampling}

Sulfate concentrations of the Neckar were measured to quantify the interaction between the river and groundwater. Sampling was performed during low water runoff on the downstream side of the weir on both sides at an approximately $100 \mathrm{~m}$ distance from one another. In addition, four samples from the headwater of the weir lock were taken.

All samples were analyzed by ion chromatography (Dionex ICS-1100) after filtering $(0.45 \mu \mathrm{m})$.

\subsection{Tracer tests}

\subsubsection{General}

Tracer tests allow to track water flow paths and to assess hydrogeological parameters. If hydraulic properties of an aquifer or non-reactive transport processes are examined, conservative tracers are suitable (Käss 2004). Especially fluorescent tracers are widely used in hydrogeology. As part of this work, the substances Uranine for the surface and Amidorhodamin G for the subsurface injections were applied as tracers.

\subsubsection{Tracer injection}

On 11 September 2013, $1 \mathrm{~kg}$ of the fluorescent dye Amidorhodamin G was injected through two groundwater monitoring wells $(0.5 \mathrm{~kg}$ per well) directly into the lower aquifer, respectively. The injection wells were selected on the eastern and on the western river banks in the headwater area of the weir lock, due to their symmetrical position on both sides of the weir lock (Figure 4(a)). In addition, the hydraulic connection with the aquifer was tested previously by hydraulic tests and borehole dilution tests to ensure the discharge of the tracer into the aquifer (Blechschmidt 2013). 


\section{Autorenfassung}

Strasser, Montenegro, Blechschmidt, Liesch, Goldscheider: Multi-tracer approach to characterize hydraulically induced sulfate rock dissolution processes below a weir lock, 2016

Due to the prevailing groundwater flow conditions in close range to the weir lock (cf. Figure 3), Amidorhodamin G could be used at two points simultaneously. Caused by the flow around the structure an

Strasser, Montenegro, Blechschmidt, Liesch, Goldscheider: Multi-tracer approach to characterize hydraulically induced sulfate rock dissolution processes below a weir lock. Journal of Applied Water Engineering and Research 20 April 2016 (2016), S. 1-16.

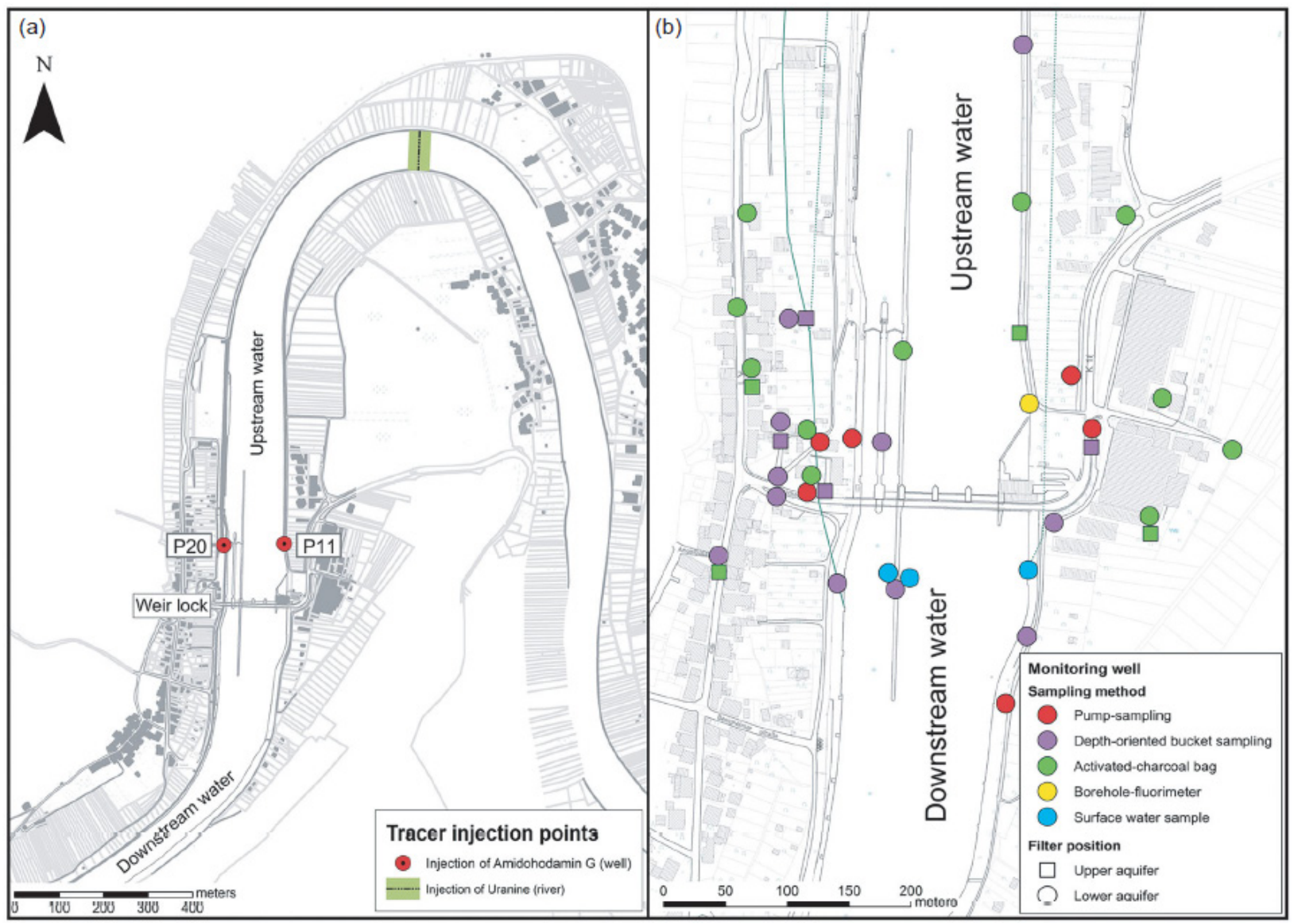

Figure 4. Position of tracer injection points (a) and the monitoring wells (b) in the area of the weir lock Hessigheim.

interaction from one side to the other can be excluded. The dissolved tracer and the required rinsing water were pumped directly into the level of the filter screens.

For the surface-subsurface experiment, $5 \mathrm{~kg}$ of diluted Uranine were poured from a boat into the Neckar along a cross-section at the apex of the meander between Hessigheim and Mundelsheim (Figure 4(a)) aiming at an even distribution and complete mixing in the stream. 


\section{Autorenfassung}

Strasser, Montenegro, Blechschmidt, Liesch, Goldscheider: Multi-tracer approach to characterize hydraulically induced sulfate rock dissolution processes below a weir lock, 2016

\subsubsection{Monitoring}

Immediately after the injections, a monitoring program was started, which was adjusted to the test sequence. Groundwater and surface water samples were taken in a high-resolution time series at 46 different locations. The sampling method was adjusted in accordance with the respective requirements of the collection points. Due to totally different boundary conditions, for example, differing diameters and depth of monitoring wells, various sampling methods had to be applied. The location of the sampling points and the type of sampling are shown in Figure 4(b). During the first $6 \mathrm{~d}$, samples were taken in a $3 \mathrm{~h}$ time interval, including depth-integrated bucket samples from 16 groundwater monitoring wells, pump samples from 6 groundwater monitoring wells and bucket samples from 3 points along the Neckar River. Thereafter, the sampling interval was gradually increased to $4 \mathrm{~h}$ and later to 6 and $12 \mathrm{~h}$ until 23 September. Up to 3 October, all measuring points were sampled twice a week, afterwards on a weekly basis until 17 October. Then, the intervals were systematically extended. In addition to the discrete sampling, a borehole fluorimeter yielded continuous measurements in one observation well. Furthermore, 15 groundwater monitoring wells were sampled with activated charcoal bags for qualitative information, on which the tracer substances are easily adsorbed. In the beginning, these were changed daily. During the course of the monitoring time the intervals were extended.

Before injecting the tracer, blind samples were taken at all monitoring points in order to exclude any existing initial concentration of the applied substances.

\subsubsection{Chemical analysis}

The tracer samples were analyzed by fluorimetry (Perkin Elmer LS 55). The detection limit of Uranine is, depending on the test conditions, at $0.002 \mu \mathrm{g} / \mathrm{L}$ and of Amidorhodamin $\mathrm{G}$ at $0.007 \mu \mathrm{g} / \mathrm{L}$ (LFU Bayern 2002).

Strasser, Montenegro, Blechschmidt, Liesch, Goldscheider: Multi-tracer approach to characterize hydraulically induced sulfate rock dissolution processes below a weir lock. Journal of Applied Water Engineering and Research 20 April 2016 (2016), S. 1-16.

\subsubsection{Determination of subsurface transport parameters}

The maximum and the average flow velocity as well as the dispersion coefficient are among the key parameters for the description of subsurface transport. Most of the approaches for the determination of subsurface transport parameters are based on substantial simplifications. The advectiveand dispersive subsurface transport is regarded as a kind of Brownian movement and thus represented based on Fick's second law (Fick 1855). The temporal concentration variation in one dimension reads: 


\section{Autorenfassung}

Strasser, Montenegro, Blechschmidt, Liesch, Goldscheider: Multi-tracer approach to characterize hydraulically induced sulfate rock dissolution processes below a weir lock, 2016

$$
\frac{\mathrm{d} c}{\mathrm{~d} t}=D_{l} \frac{\mathrm{d}^{2} c}{\mathrm{~d} x^{2}}-v_{m} \frac{\mathrm{d} c}{\mathrm{~d} x}
$$

with the longitudinal dispersion coefficient $\mathrm{D}_{1}\left[\mathrm{~m}^{2} / \mathrm{s}\right]$, the mean linear fluid velocity $\mathrm{V}_{\mathrm{m}}[\mathrm{m} / \mathrm{s}]$ and the tracer concentration $\mathrm{c}[\mathrm{g} / \mathrm{L}]$.

Assuming a Gaussian distribution around the maximum concentration $\mathrm{c}_{\max }$, the concentration c after a pulse-like injection at location $\mathrm{x}[\mathrm{m}]$ at time $\mathrm{t}$ [s] can be evaluated as (Käss 2004):

$$
c(x, t)=c_{\max , t} \cdot e^{\left(x-v_{m} \cdot t\right)^{2} /\left(-4 \cdot D_{l} \cdot t\right)} .
$$

The measured breakthrough curves are approximated by fitting with an exponential function and yielding the unknown parameters: average flow velocity $v_{m}$ and the spersion coefficient $D_{1}$. The average flow velocity $v_{m}$ characterizes the average velocity of a water particle. In order to estimate the Darcy velocity or specific discharge $v_{f}$ required for Darcy's law (Darcy 1856), the effective porosity $\mathrm{n}[-]$ must be considered:

$$
v_{f}=v_{m} \cdot n=-k_{f} \cdot i
$$

Rearranging Equation (4), assuming laminar flow and using the observed hydraulic gradient i [-], the hydraulic conductivity $\mathrm{k}_{\mathrm{f}}[\mathrm{m} / \mathrm{s}]$ can be calculated as follows:

$$
k_{f}=\frac{v_{m} \cdot n}{i} \text {. }
$$

The permeability coefficient determined with tracer tests can only represent the local flow paths and is thus limited to a small geological area. Furthermore Darcian flow with laminar flow conditions through a homogeneous porous medium with constant hydraulic conductivity and porosity is not necessarily met.

In a fractured subsurface dispersion results in a flattening of the breakthrough curve and represents velocity variability due to different flow paths of contrasting transport velocities. Accordingto Käss (2004), the dispersion coefficient $\mathrm{D}_{1}$ depends linearly on the flow rate:

$$
D_{l}=\alpha_{l} \cdot v_{m}
$$

where $\alpha_{1}$ is longitudinal dispersivity [m]. The dispersivity describes the heterogeneity of the flow within the porous medium, a characteristic value of the rock or the subsoil. The impact of heterogeneity on the dispersive transport increases with the length of the low paths and therefore the dispersivity also shows a correlation with the distance to the injection point. Values for the dispersivity range from 10 to $1000 \mathrm{~m}$ for fractured and karstic aquifers and for porous aquifers, depending on the length of the flow path, between 0.1 and $100 \mathrm{~m}$ (Käss 2004). 


\section{Autorenfassung}

Strasser, Montenegro, Blechschmidt, Liesch, Goldscheider: Multi-tracer approach to characterize hydraulically induced sulfate rock dissolution processes below a weir lock, 2016

For the described inverse parameter identification, analytical models of varying complexity can be applied. The simplest is the advection-dispersion model (ADM) described by Equation (2). Particularly for karstic aquifers, a model that incorporates mobile and immobile fluid regions in the flow field offers more flexibility. The latter is referred to as 2-region-non-equilibrium model (2RNE) (Toride et al.1993). During the fitting of the measured breakthrough curve in addition to the mean velocity and the dispersion coefficient two additional parameters, $\beta$ and $\omega$ (Figure 5), considering the mobile/immobile interactions mustbe considered. The distribution coefficient $\beta$ describes the proportion of mobile fluid region in the total flow. It can take values between 0 and 1 , where 1 represents only mobile solution transports. The exchange coefficient $\omega(\omega<1)$ indicates the degree of exchange between the mobile and the immobile phases. Higher values indicate more intensive exchange. Particularly breakthrough curves with a long tailing, that is, a delayed decrease of tracer concentration, can be adapted better with this approach (Goldscheider 2008). In the event of a lesser hydraulic connection between insertion point and collecting point, the mass transfer is determined only to a small extent by the mobile phase. Large parts of the tracer are released into the less permeable areas or stay in dead end pore spaces or karst cavities at lesser flow. The form of the breakthrough curve is, therefore, dominated by immobile zones and not only influenced by dispersivity and average flow velocity. These parameters are consequently less significant compared to the ADM model. The 2RNE model with

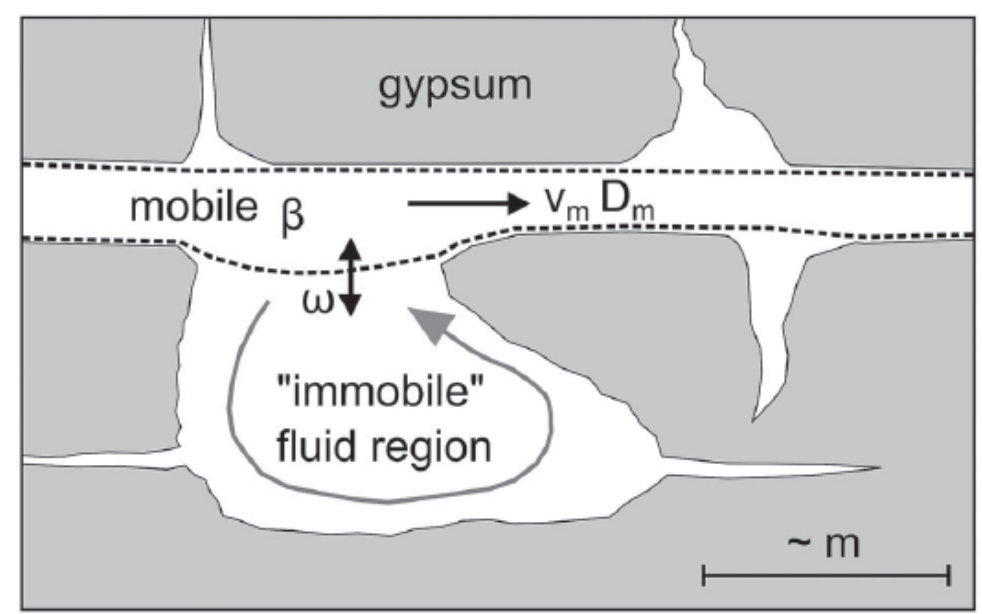

Figure 5. Representation of the subsurface transport parameters, mean flow velocity $\mathrm{v}_{\mathrm{m}}$, average dispersion coefficient $D_{m}$, distribution coefficient $\beta$ and exchange coefficient $\omega$ for a karst aquifer (modified after Goldscheider 2008). 


\section{Strasser, Montenegro, Blechschmidt, Liesch, Goldscheider: Multi-tracer} approach to characterize hydraulically induced sulfate rock dissolution processes below a weir lock. Journal of Applied Water Engineering and Research 20 April 2016 (2016), S. 1-16.

two additional parameters $\beta$ and $\omega$ reproduces the subsurface transport conditions in the area of the weir lock Hessigheim, which is also reflected in the improved reproduction of the breakthrough curve tailings and thus has higher coefficients of determination.

\section{Results}

\subsection{Hydraulic borehole investigations}

The hydraulic conductivity of the lower aquifer varies between $1 \times 10^{-7}$ and $7.6 \times 10^{-5} \mathrm{~m} / \mathrm{s}$. The results of sluginjection tests and the pumping and recovery test are shown in Figure 3.

The highest value of hydraulic conductivity of $7.6 \times 10^{-5} \mathrm{~m} / \mathrm{s}$ was determined on the eastern bank at measuring point P10 (Figure 3). The western bank shows an inhomogeneous distribution of hydraulic conductivity. At the measuring points P20 and P28, which are close to the bank, hydraulic conductivities of about $1 \times 10^{-5} \mathrm{~m} / \mathrm{s}$ were determined. In the area of the upstream side of the breakwater wall (P26), a similar hydraulic permeability was determined. In the immediate vicinity of the grout curtain west of the weir lock areas of low permeability were identified. Here, values were determined in the range of about $1 \times 10^{-7} \mathrm{~m} / \mathrm{s}$.

The borehole dilution tests revealed Darcy velocities between $7.6210^{-5}(\mathrm{P} 11)$ and $1.28 \times 10^{-3} \mathrm{~m} / \mathrm{s}$ (P20) in the lower aquifer (Figure 6). Spread over the depth, zones of high and low Darcy velocity were identified. In P11 only one high velocity zone could be recognized, whereas in P20 there were two. The horizons with higher conductivity have a thickness of about $0.3 \mathrm{~m}$ and can be interpreted as zones of higher karstification in the Upper Clay-Anhydrite-Formation (lower aquifer).

\subsection{Sulfate concentration}

Figure 7 shows the distribution of sulfate concentration in groundwater of the upper and lower aquifers in the vicinity of the weir lock. Compared to the average sulfate concentration of natural groundwater in Germany $(10-100 \mathrm{mg} / \mathrm{L}$ ) and the German limit for drinking water of $250 \mathrm{mg} / \mathrm{L}$ (Trinkw 2001) the measured concentrations in the Middle Muschelkalk in the area around the weir lock Hessigheim (293-1951 mg/L) are significantly increased.

The groundwater in the Middle Muschelkalk, in the area of the weir lock, shows higher concentrations on the western bank compared to the eastern bank, with an average concentration of 


\section{Autorenfassung}

Strasser, Montenegro, Blechschmidt, Liesch, Goldscheider: Multi-tracer approach to characterize hydraulically induced sulfate rock dissolution processes below a weir lock, 2016

$1056 \mathrm{mg} / \mathrm{L}$. In measuring point P37 (western bank), a maximum value of $1951 \mathrm{mg} / \mathrm{L}$ was determined. The lowest concentration of $293 \mathrm{mg} / \mathrm{L}$ was measured in P11 (eastern bank). A number of exploratory drillings (Wittke 1998) show that the Upper Clay-Anhydrite-Formation (lower aquifer) is only present in a layer of very small thickness in the range of the measurement points on the eastern bank. The greater part has already been dissolved and the resulting cavities filled with residual clay. Therefore, scarcely any soluble material is left. Large layer thicknesses in the Upper Clay-Anhydrite- Formation were only encountere $\mathrm{at}$ the measuring points $\mathrm{P} 4$ and $\mathrm{P} 5$ by exploratory drilling.

The interpolated concentration distribution of sulfate in the upper aquifer in September 2013 is shown in Figure 7(b). On average, compared to the lower aquifer, lower values were determined with significant differences
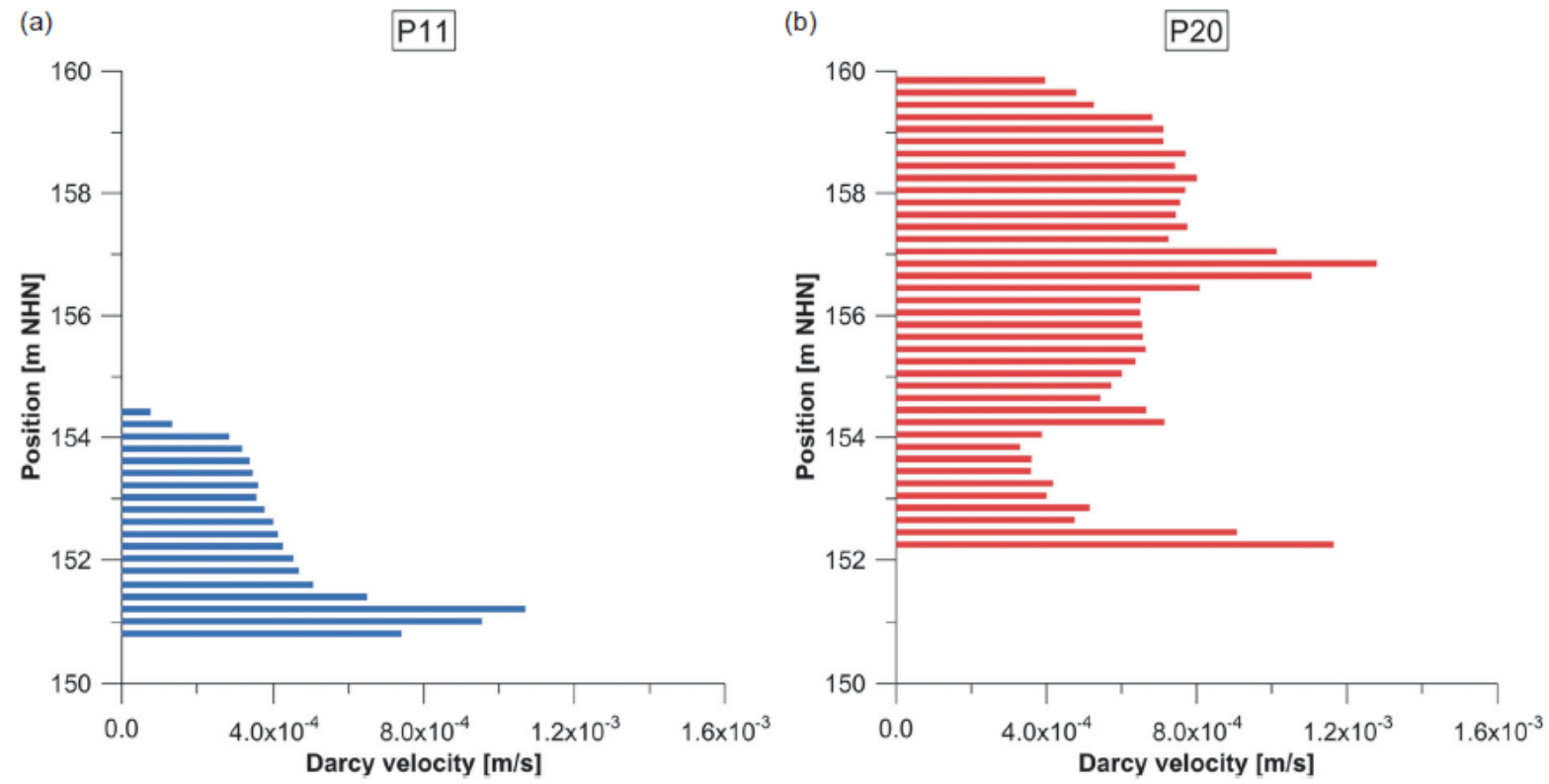

Figure 6. Darcy velocities determined by borehole dilution tests in wells P11 and P20.

Strasser, Montenegro, Blechschmidt, Liesch, Goldscheider: Multi-tracer approach to characterize hydraulically induced sulfate rock dissolution processes below a weir lock.

Journal of Applied Water Engineering and Research 20 April 2016 (2016), S. 1-16. 


\section{Autorenfassung}

Strasser, Montenegro, Blechschmidt, Liesch, Goldscheider: Multi-tracer approach to characterize hydraulically induced sulfate rock dissolution processes below a weir lock, 2016

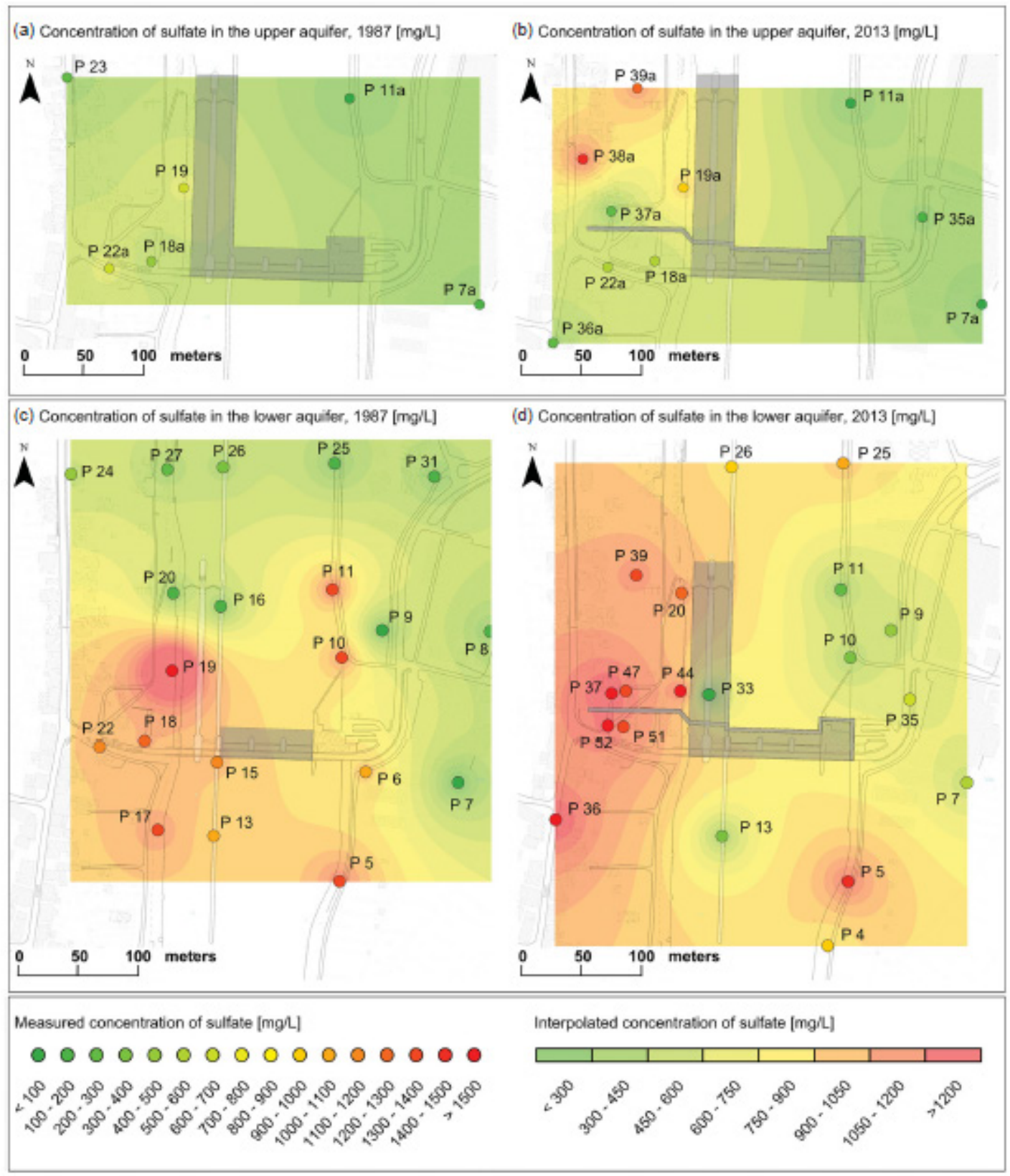

Figure 7. Spatial interpolation of the dissolved sulfate concentration of groundwater in the area of the upper aquifer (Neckar gravel) $(\mathrm{a}+\mathrm{b})$ and in the lower aquifer (Middle Muschelkalk) $(c+d)$ each based on two test days in 1987 and 2013.

between the western and the eastern banks. The highest concentration was measured on the western bank with $1400 \mathrm{mg} / \mathrm{L}$. In measuring point P7a and P11a, on the eastern bank, significantly lower values were determined with 73 and $92 \mathrm{mg} / \mathrm{L}$, respectively. These values are even lower than the concentration measured in the Neckar surface water.

The groundwater's sulfate content in the area of the Hessigheim weir lock was already determined in 1987 (Wittke 1998). The results are shown in Figure 7(a) for 


\section{Autorenfassung}

Strasser, Montenegro, Blechschmidt, Liesch, Goldscheider: Multi-tracer approach to characterize hydraulically induced sulfate rock dissolution processes below a weir lock, 2016

Strasser, Montenegro, Blechschmidt, Liesch, Goldscheider: Multi-tracer approach to characterize hydraulically induced sulfate rock

dissolution processes below a weir lock.

Journal of Applied Water Engineering and Research 20 April 2016 (2016), S. 1-16.

the upper aquifer (Neckar gravel) and in Figure 7(c) for the lower aquifer (Middle Muschelkalk). On average the values were generally lower in 1987 compared to 2013. The highest concentration was measured downstream the weir on the western bank in measuring point $\mathrm{P} 17$ with $1337 \mathrm{mg} / \mathrm{L}$ in the Middle Muschelkalk. The concentration increase from north to south shows that the groundwater enriches itself with sulfate during the flow around the weir lock area. The concentration differences between the eastern and western bank were much lower in 1987 compared to 2013 .

The concentrations of sulfate in the Neckar River upstream the weir shows little variation around a mean of $156.7 \mathrm{mg} / \mathrm{L}$. Hence, almost constant sulfate concentration in the headwater can be assumed. The middle weir segment was slightly open on the day of sampling, despite low runoff. However, the main outflow occurred on the power plant on the eastern bank.

In contrast to the headwater, the tailwater area shows variation in sulfate concentrations of river water samples. The average concentration of tailwater is $158.2 \mathrm{mg} / \mathrm{L}$.

It has to be noted that the dissolved sulfate concentration of surface water was not taken into consideration for the spatial interpolation shown in Figure 7.

\subsubsection{Estimation of groundwater inflow using mixing calculation}

The measured sulfate concentrations were used in a mixing calculation to determine the local influx of groundwater into the Neckar River downstream of the weir lock. For this purpose, concentrations measured in groundwater and surface water samples were used. The mixing calculation can be formulated as follows:

$$
Q_{\mathrm{tw}} \cdot c_{\mathrm{tw}}=Q_{\mathrm{hw}} \cdot c_{\mathrm{hw}}+Q_{\mathrm{gw}} \cdot c_{\mathrm{gw}}
$$

where $c_{t w}$ describes the sulfate concentration in tailwater $[\mathrm{mg} / \mathrm{L}]$, $\mathrm{c}_{\mathrm{hw}}$ in headwater and $\mathrm{c}_{\mathrm{gw}}$ in groundwater. $\mathrm{Q}_{\mathrm{tw}}\left[\mathrm{m}^{3} / \mathrm{s}\right]$ denotes the tailwater's runoff rate, $\mathrm{Q}_{\mathrm{hw}}$ the headwater's runoff rate and $\mathrm{Q}_{\mathrm{gw}}$ the groundwater influx.

By using the assumption $\mathrm{Q}_{\mathrm{hw}}=\mathrm{Q}_{\mathrm{tw}}-\mathrm{Q}_{\mathrm{gw}}$, Equation (7) can be rearranged to:

$$
Q_{\mathrm{gw}}=Q_{\mathrm{tw}} \cdot \frac{c_{\mathrm{tw}}-c_{\mathrm{hw}}}{c_{\mathrm{gw}}-c_{\mathrm{hw}}}
$$




\section{Autorenfassung}

Strasser, Montenegro, Blechschmidt, Liesch, Goldscheider: Multi-tracer approach to characterize hydraulically induced sulfate rock dissolution processes below a weir lock, 2016

For the calculations the median sulfate concentration in groundwater of $1056.5 \mathrm{mg} / \mathrm{L}$ was used. Median surface water sulfate concentrations upstream (156.7 mg/L) and downstream $(158.2 \mathrm{mg} / \mathrm{L})$ of the weir lock were also taken into account. The downstream runoff rate of the Neckar was $68.0 \mathrm{~m}^{3} / \mathrm{s}$ on the sampling day.

The balancing calculation results in a groundwater influx of $0.11 \mathrm{~m}^{3} / \mathrm{s}$, about $0.17 \%$ of the total runoff. This is based on the assumption that the increased sulfate concentrations are due to influxes from the lower aquifer. However, this ascription to the lower aquifer is only a rough estimate. This model does not include quantities for water flowing around the dam area above the Neckar gravel and also disregards possible infiltration of lower mineralized water from the slopes on the eastern side. In order to extend the validity of the balancing calculation, the calculation was repeated considering only the downstream groundwater sampling sites (P4, P5, P36, P51, P52). With a median concentration of $1469.49 \mathrm{mg} / \mathrm{L}$ a groundwater influx of $0.08 \mathrm{~m}^{3} / \mathrm{s}$, about $0.11 \%$ of the total runoff, was calculated.

\subsection{Groundwater tracer test}

Amidorhodamin G was detected in the monitoring points P10, P22, P35 and P40, which have filter sections located in the lower aquifer (Middle Muschelkalk), as well as in the upper aquifer in well P18a.

For two sampling points, $\mathrm{P} 10$ and P40, the tracer detections allowed the construction and quantitative analysis of a breakthrough curve (Figures 8 and 9). A rising concentration is still being registered to this day at P18a, hindering a complete evaluation for this point. Nevertheless, conclusions concerning geohydraulic processes in the study area can still be drawn from P18a.

The results and input parameters used for the evaluation with the 2RNE model are shown in Table 1.

An evaluation of measuring point P10 with a distance of 58m from P11 was performed with the ADM and 2RNE methods. Figure 8 shows the concentration curve at the corresponding collection point. These values were recorded with a permanently installed in situ borehole 


\section{Autorenfassung}

Strasser, Montenegro, Blechschmidt, Liesch, Goldscheider: Multi-tracer approach to characterize hydraulically induced sulfate rock dissolution processes below a weir lock, 2016

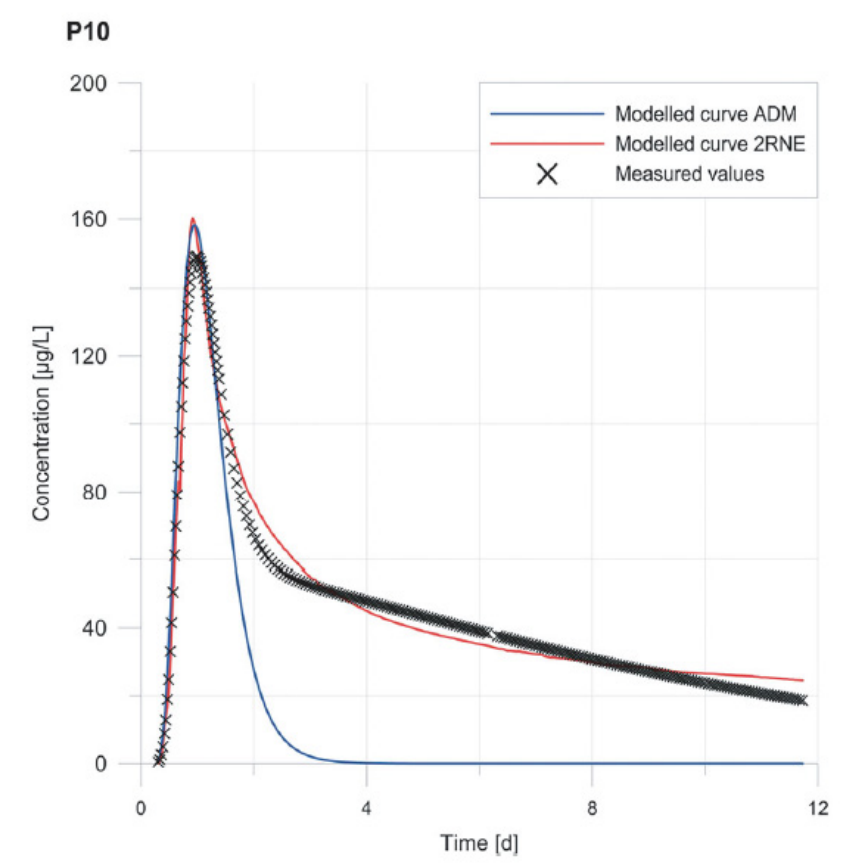

Figure 8. Measured tracer concentration and modeled breakthrough curve (P10).

Strasser, Montenegro, Blechschmidt, Liesch, Goldscheider: Multi-tracer approach to characterize hydraulically induced sulfate rock dissolution processes below a weir lock.

Journal of Applied Water Engineering and Research 20 April 2016 (2016), S. 1-16.

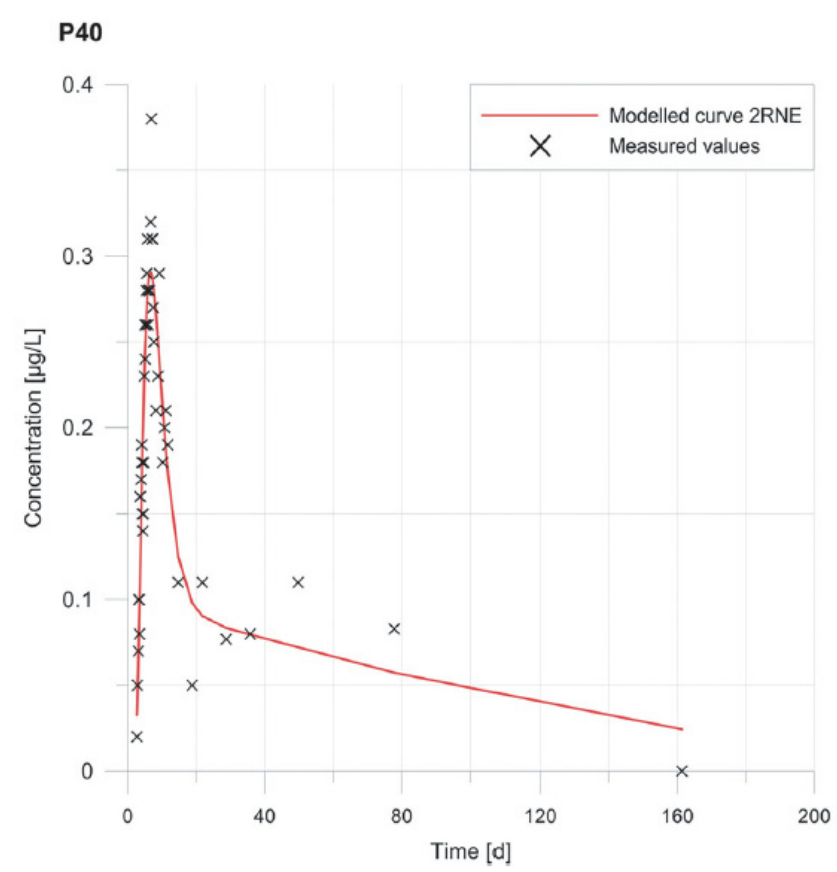

Figure 9. Measured values of tracer concentration and modeled breakthrough curve (P40). 


\section{Autorenfassung}

Strasser, Montenegro, Blechschmidt, Liesch, Goldscheider: Multi-tracer approach to characterize hydraulically induced sulfate rock dissolution processes below a weir lock, 2016

fluorimeter, which was calibrated with groundwater samples taken from the same measuring points. This reduced errors attributable to background concentration and aging of the device. Amidorhodamin $\mathrm{G}$ was first detected after $7.32 \mathrm{~h}$ and reached a peak concentration of $160.19 \mu \mathrm{g} / \mathrm{L}$ after $21.85 \mathrm{~h}$. An average velocity of $0.35 \mathrm{~m} / \mathrm{h}$ with a dispersion coefficient of $1.78 \mathrm{~m}^{2} / \mathrm{h}$ for the hydraulic connection between the two sampling points near the eastern bank was modeled based on the 2RNE method. AMD and 2RNE fitting produced significantly different curves. Overall the 2RNE curve matches the measured values better, indicating that this model reflects the natural conditions more accurately. For this reason, the $2 \mathrm{RNE}$ method was also applied to $\mathrm{P} 40$. The model determined the proportion of the mobile phase and the exchange coefficient to be 0.21 and 0.03 , respectively. Furthermore, the hydraulic connection between P11 and P10 has a higher flow velocity and the measuring point is better connected to the flow system.

Groundwater samples from P35 contain detectable amounts of Amidorhodamin G, though the measured concentrations are only slightly above the detection limit. Thus, the results are prone to error. The first concentration detection in a groundwater sample was after $14 \mathrm{~d}$ and $19 \mathrm{~h}$. After a further $14 \mathrm{~d}$, a higher concentration of $0.1 \mu \mathrm{g} / \mathrm{L}$ was measured. With a distance of $105 \mathrm{~m}$ from the insertion point $\mathrm{P} 11$, the maximum velocity was calculated as $0.30 \mathrm{~m} / \mathrm{h}$ and is, therefore, very close to the average flow velocity between the measurement points P11 and P10, which are also located on the eastern bank. Over a period of four months, the measured values fluctuated from 0.06 to $0.12 \mathrm{~g} / \mathrm{L}$ and showed no clear peak or trend. The measurements are therefore not suitable for analysis; the presence of the tracer was, however, proven without doubt.

Sampling point P40 is located at a distance of $89 \mathrm{~m}$ from the injection point P20 on the western banks of the Neckar. The measured values show strong scattering around the peak as well as tailing (Figure 9), which may be due to slight differences in the sampling techniques and very small detected concentrations.

The tracer was first detected after $2 \mathrm{~d}$ and $16 \mathrm{~h}$, reaching the peak concentration of $0.38 \mathrm{~g} / \mathrm{L}$ after $6 \mathrm{~d}$ and $22 \mathrm{~h}$. Based on a distance of $89 \mathrm{~m}$ from the injection point, this results in a maximum flow velocity of $1.38 \mathrm{~m} / \mathrm{h}$ and a peak velocity (dominant flow velocity) of $0.54 \mathrm{~m} / \mathrm{h}$. The concentration decreases to $0.05 \mu \mathrm{g} / \mathrm{L}$ around the tailings. Curve fitting with the $2 \mathrm{RNE}$ model is in good agreement with the results of the measurements and has a coefficient of determination of 0.88 . By adjusting the modeled breakthrough curve to the measured values, a mean velocity of $0.03 \mathrm{~m} / \mathrm{h}$, a dispersion coefficient of $0.52 \mathrm{~m}^{2} / \mathrm{h}$ and $17.63 \mathrm{~m}$ for the

\begin{tabular}{|l|l|l|l|l|l|l|}
\hline Sampling point & Symbol & Unit & $\mathrm{P} 10$ & $\mathrm{P} 40$ & $\mathrm{P} 35$ & $\mathrm{P} 18 \mathrm{a}$ \\
\hline $\begin{array}{l}\text { Distance from the injection point } \\
\text { (P11 for P10 and P35 and P20 for } \\
\text { P40 and P18a) }\end{array}$ & $\mathrm{x}$ & $\mathrm{m}$ & 58 & 89 & 105 & 126 \\
\hline First detection time & $\mathrm{t}_{1}$ & $\mathrm{~d}$ & 0.31 & 2.69 & 14.80 & 77.83 \\
\hline
\end{tabular}




\section{Autorenfassung}

Strasser, Montenegro, Blechschmidt, Liesch, Goldscheider: Multi-tracer approach to characterize hydraulically induced sulfate rock dissolution processes below a weir lock, 2016

\begin{tabular}{|l|l|l|l|l|l|l|}
\hline Peak time & $\mathrm{t}_{\mathrm{p}}$ & $\mathrm{d}$ & 0.91 & 6.91 & - & - \\
\hline Peak concentration & $\mathrm{c}_{\mathrm{p}}$ & $\mu \mathrm{g} / \mathrm{L}$ & 160.19 & 0.38 & - & - \\
\hline Maximal velocity & $\mathrm{v}_{\max }$ & $\mathrm{m} / \mathrm{h}$ & 7.92 & 1.38 & 0.30 & 0.07 \\
\hline Peak velocity & $\mathrm{v}_{\mathrm{p}}$ & $\mathrm{m} / \mathrm{h}$ & 2.65 & 0.54 & - & - \\
\hline Average velocity & $\mathrm{v}_{\mathrm{m}}$ & $\mathrm{m} / \mathrm{h}$ & 0.35 & 0.03 & - & - \\
\hline Longit. Dispersion coefficient & $\mathrm{D}_{\mathrm{l}}$ & $\mathrm{m}{ }^{2} / \mathrm{h}$ & 1.78 & 0.52 & - & - \\
\hline Distribution coefficient & $\mathrm{B}$ & - & 0.21 & 0.12 & - & - \\
\hline Exchange coefficient & $\omega$ & - & 0.03 & 0.03 & - & - \\
\hline Longit. dispersivity & $\alpha_{\mathrm{l}}$ & $\mathrm{m}$ & 5.09 & 17.63 & - & - \\
\hline Coefficient of determination & $\mathrm{R}^{2}$ & - & 0.98 & 0.88 & - & - \\
\hline
\end{tabular}

Table 1. Results of the modeled (2RNE model) breakthrough curves of Amidorhodamin G (P10, $\mathrm{P} 40$ ) and results based on measured tracer concentrations (P35, P18a).

\section{Strasser, Montenegro, Blechschmidt, Liesch, Goldscheider: Multi-tracer} approach to characterize hydraulically induced sulfate rock dissolution processes below a weir lock.

Journal of Applied Water Engineering and Research 20 April 2016 (2016), S. 1-16.

dispersivity could be determined. The proportion of the mobile fluid region $\beta$ was calculated to be $0.12,9 \%$ lower than in measuring point P10 and the exchange coefficient $\omega$ between the mobile and immobile fluid regions to 0.03 . This indicates that the mobile fluid region is only a minor part of the total flow and exchange rates are also small. The values of the exchange coefficients are the same for P10 and P40 and the ones of the distribution coefficients are in the same order of magnitude, indicating a good agreement of the two modeling results.

P18a is also located on the western bank at a distance of $126 \mathrm{~m}$ from the injection point (P20) downstream of the grout curtain. The tracer Amidorhodamin G was first detected after $78 \mathrm{~d}$ in groundwater samples. The maximum flow velocity is, therefore, $0.07 \mathrm{~m} / \mathrm{h}$. The measured concentrations rise continuously since then from $0.11 \mathrm{~g} / \mathrm{L}$ to $0.83 \mathrm{~g} / \mathrm{L}$ in $267 \mathrm{~d}$. A final evaluation of the results of P18a is not yet possible; however, some information can be gained at this stage. The observed maximum flow velocity is substantially lower than the hydraulic link between P20 and P40. 


\section{Autorenfassung}

Strasser, Montenegro, Blechschmidt, Liesch, Goldscheider: Multi-tracer approach to characterize hydraulically induced sulfate rock dissolution processes below a weir lock, 2016

The tracer Amidorhodamin G could not be detected in any other well. The upper aquifer well P18a is so far the only measuring point in the downstream area of the weir lock, behind the grout curtain, showing an arrival of Amidorhodamin G.

\subsection{Surface water tracer test}

On the western bank, Uranine was clearly detected in P38a in the upper aquifer and in P23 and P38 in the lower aquifer (Figure 10), proving a hydraulic connection of the

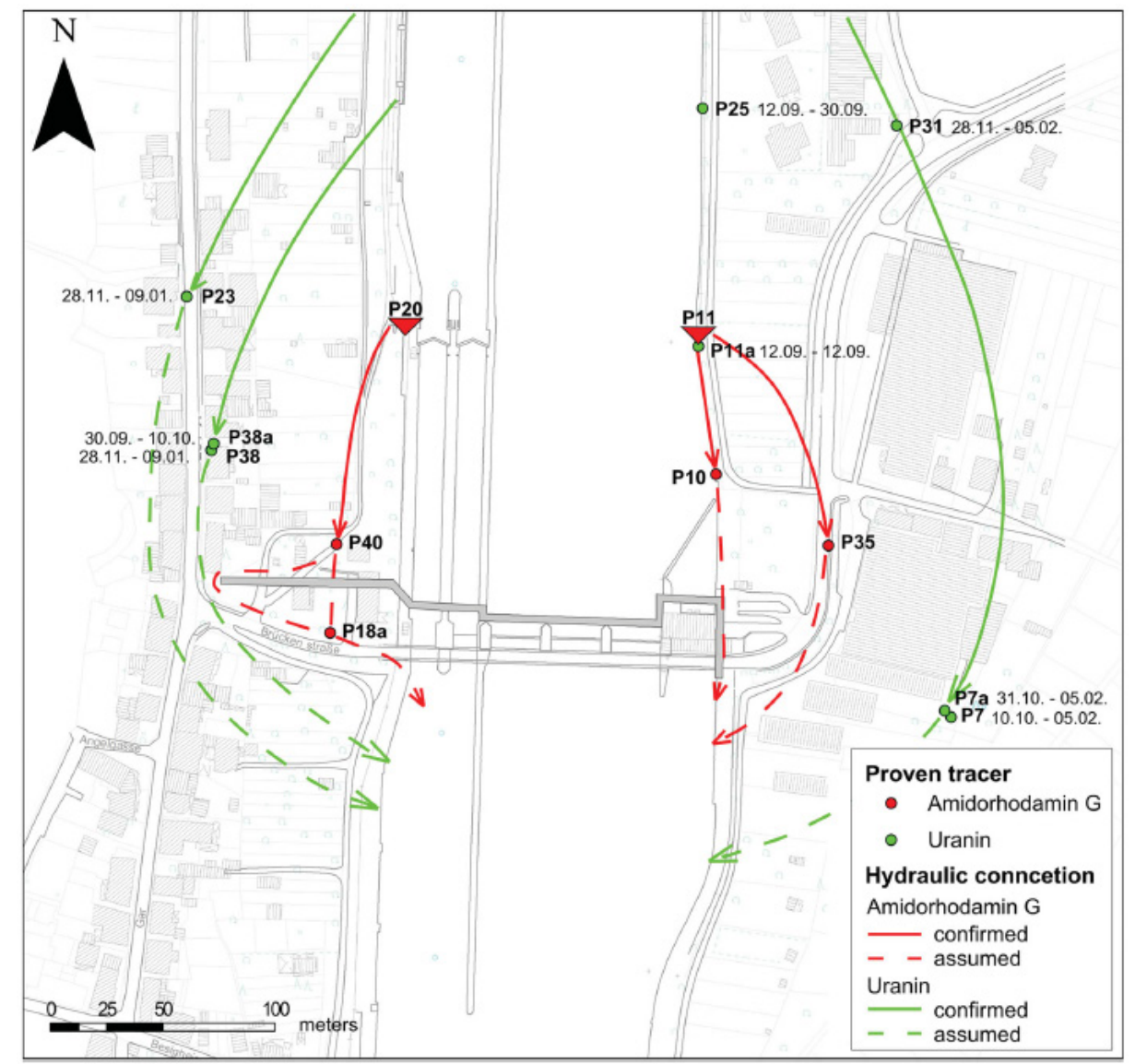

Figure 10. Dispersion of the tracers Uranine and Amidorhodamin $\mathrm{G}$ in the bedrock. Amidorhodamin G was injected into the wells P11 and P20. The lower case ' $a$ ' in the labels indicates wells filtered in the upper aquifer, the Neckar gravel. 


\section{Autorenfassung}

Strasser, Montenegro, Blechschmidt, Liesch, Goldscheider: Multi-tracer approach to characterize hydraulically induced sulfate rock dissolution processes below a weir lock, 2016

Strasser, Montenegro, Blechschmidt, Liesch, Goldscheider: Multi-tracer approach to characterize hydraulically induced sulfate rock dissolution processes below a weir lock.

Journal of Applied Water Engineering and Research 20 April 2016 (2016), S. 1-16.

two aquifers upstream the weir. Similar hydraulic conditions can be assumed for the eastern bank. Here, Uranine was detected in P11a in the upper aquifer directly on the bank and in P7a further away from the Neckar, as well as in the lower aquifer wells P7, P25 and P31. In both cases, the river water marked with the tracer either passes through the upper aquifer or directly via fractures in the river bed in the lower aquifer. Since the ground below the weir was subject to numerous grouting measures and should be in consequence mostly impermeable, the water probably flows around the weir in the bank areas. The tracer was detectable up to $100 \mathrm{~m}$ away from both banks in lower aquifer wells, indicating a quite large flow around area. Since the tracer was detected in upper aquifer wells as well as several close by lower aquifer wells (P7 and P7a, or P38 and P38a), this leads to the conclusion that a good hydraulic connection between the two aquifers exists.

\section{Discussion}

Based on the results of the described investigations a conceptual model of the complex geohydraulic situation of the area surrounding the weir lock was elaborated. All of the individual geohydraulic methods performed in Hessigheim can only provide fractional information, for example, about flow paths, groundwater potential distribution, leaching depth or the position of the current leaching horizon. Only a combined discussion of the different method's results leads to a complete picture of the geohydraulic situation. For this purpose, the results of hydraulic investigations, hydrogeochemical investigations and a combined groundwater and surface water tracer test were evaluated.

Prior to the hydrogeochemical investigations and the time-consuming tracer tests, first information concerning the hydraulic situation was gained by performing hydraulic tests in 12 wells in the investigation area. The hydraulic conductivity in the area could be quantified within a range between $1.0 \times 10^{-7}$ and $7.6 \times 10^{-5} \mathrm{~m} / \mathrm{s}$ by nine sluginjection tests and three pumping tests. The results of the hydraulic investigations suggest the zones in immediate vicinity to the river to be more permeable than those which are further away from the river. This could indicate a more advanced leaching process in zones bordering the river and consequently a minor sulfate solution from a certain distance to the river. At this point of the investigation process, this could not be conclusively clarified. Given the limited number of available wells, the results could still be caused by the natural heterogeneity of the aquifer. Hydraulic borehole investigations provide exact but only punctual information. Extrapolating within a heterogeneous aquifer is not possible or strongly prone to error.

Accompanying the previously discussed investigations, borehole dilution tests were performed in the wells P11 and P20. Gaining more information about the hydraulic connection between these 


\section{Autorenfassung}

Strasser, Montenegro, Blechschmidt, Liesch, Goldscheider: Multi-tracer approach to characterize hydraulically induced sulfate rock dissolution processes below a weir lock, 2016

wells and the lower aquifer as well as the natural flow velocities was important too because these were the potential tracer injection wells. Hereby, a good hydraulic connection between the wells and the lower aquifer was proven, and high velocity horizons with a minor thickness were identified. This points to a very heterogeneous aquifer in vertical orientation.

The next step of the investigation was a comprehensive study of the dissolved sulfate distribution in the area. Therefore, 30 ground water monitoring wells and numerous surface water points, upstream and downstream of the weir lock, were sampled. The concentration of dissolved sulfate in groundwater ranged between 73 and $1951 \mathrm{mg} / \mathrm{L}$. Higher concentrations were identified on the western bank, increasing with the flow direction. In general, concentrations in the lower aquifer (median: $1056 \mathrm{mg} / \mathrm{L}$ ) are significantly higher than these of the upper aquifer (median: $402 \mathrm{mg} / \mathrm{L}$ ).

In 1987, the leaching front was restricted in the east to the bank based on the observed high concentrations in P10 and P11 and the considerably lower concentrations in P7, P8 and P9. Today, the concentration distribution in this area is almost reversed; P10 and P11 have lower concentrations compared to the points further away from the river. This suggests that all dissolvable material has been leached out in the area close to P10 and P11 and the leaching front has progressed further outward in the east.

The prominent change of the concentration distribution from 1987 to 2013 is probably due to anthropogenic influences in this region since natural changes occur on much longer time-scales. The high rate of leaching is attributable to the steeper hydraulic gradient of the groundwater induced by the weir lock.

In the measuring points $\mathrm{P} 7 \mathrm{a}(73 \mathrm{mg} / \mathrm{L})$ and P11a $(92 \mathrm{mg} / \mathrm{L})$ in the upper aquifer (eastern bank), the sulfate concentration is even below that of the river itself. This indicates that in this zone the upper aquifer is fed with regional inflows of other origins, such as surface overflow from precipitation on the adjacent slopes.

The higher concentrations of sulfate in groundwater in the lower aquifer of the western bank indicate lower flow velocities, probably due to the damming effect of the installed underground grout curtain, which reduces the hydraulic gradient in this zone and thus leads to longer contact times. The huger layer thickness of the Upper Clay-Anhydrite-Formation (lower aquifer), compared to the eastern bank, provides an advanced availability of soluble material. In 2013, very high sulfate concentrations were also detected in groundwater samples taken in the upper aquifer upstream of the grout curtain (western bank). The damming effect of the grout curtain causes a rise of sulfaterich groundwater from the lower into the upper aquifer. This shows a direct hydraulic connection between the two aquifers and results in an increase in sulfate concentrations by $1000-1400 \mathrm{mg} / \mathrm{L}$ in the upper aquifer.

The sulfate concentration measured in the river was considerably lower than in groundwater. The concentration upstream the weir lock (median: $156.7 \mathrm{mg} / \mathrm{L}$ ) was only 


\section{Autorenfassung}

Strasser, Montenegro, Blechschmidt, Liesch, Goldscheider: Multi-tracer approach to characterize hydraulically induced sulfate rock dissolution processes below a weir lock, 2016

Strasser, Montenegro, Blechschmidt, Liesch, Goldscheider: Multi-tracer approach to characterize hydraulically induced sulfate rock dissolution processes below a weir lock.

Journal of Applied Water Engineering and Research 20 April 2016 (2016), S. 1-16.

marginally lower than downstream (median: $158.2 \mathrm{mg} / \mathrm{L}$ ). A balancing calculation based on measured concentrations of surface water and groundwater shows a groundwater influx of $0.097 \mathrm{~m}^{3} / \mathrm{s}$ to Neckar's tailwater. This is only about $0.14 \%$ of the total runoff.

In the course of a tracer test, $5 \mathrm{~kg}$ of the fluorescent dye Uranine was inserted into the Neckar and in total $2 \mathrm{~kg}$ of Amidohordamin G into the aquifer (1 kg in P11 and $1 \mathrm{~kg}$ in P20). Both tracers were found in groundwater monitoring wells on the eastern and western banks. The detection of Amidorhodamin $\mathrm{G}$ at sampling point $\mathrm{P} 10$ shows a direct hydraulic connection between $\mathrm{P} 11$ and $\mathrm{P} 10$, on the east bank, with a high water flow velocity. The tracer in P10 was already detected after $7 \mathrm{~h}$. The values determined from P35, located $35 \mathrm{~m}$ away from the river bank, differ strongly. Here, the arrival of the tracer was measured after $14 \mathrm{~d}$; the calculated flow velocity is correspondingly much lower. Hence, the main drain runs along the bank close to the power plant.

On the western bank, the tracer Amidorhodamin G was detected in P40 $2 \mathrm{~d}$ after insertion into P20. The dispersivity is higher; the amount of the mobile phase and the flow velocity is lower compared to the hydraulic connection between P10 and P11 on the eastern bank. This could be due to the damming effect of the grout curtain. The grout curtain, which extends approximately $80 \mathrm{~m}$ across the western bank, causes a reduction of the hydraulic gradient and in turn a lower flow velocity in this area as opposed to the eastern bank, where the grout curtain ends at the bank.

There are only a few measuring wells located in the tailwater area of the weir lock. None of these had detectable amounts of the tracer on the eastern bank and only one on the western bank. The tracer was detected after $78 \mathrm{~d}$ downstream of the grout curtain in P18a. Since P18a is an upper aquifer well, the tracer has to be transported from the lower into the upper aquifer, which proves a hydraulic connection. Thus, the flow path follows a vertical gradient, which extends upwards in the impeding grout curtain. Since P18s is located downstream of the grout curtain, the water either flows through the curtain itself, indicating it is not completely impermeable, or around it. An underflow of the curtain seems to be less likely. If there were such underflow, increased values would be detectable in P18, a measuring point at the same location as P18a but with a filter screen in the lower aquifer. A flow around cannot be totally excluded but is less likely, because the grout extends $80 \mathrm{~m}$ further to the west. Moreover, no additional measuring points in the western area show elevated levels of the tracer concentration despite there only being lower aquiferwells. Thus, a lateral circumflow in the Neckar gravel would be supposedly possible. In this respect, the tracer test confirms the previous assumptions based on water level measurements.

Uranine was only identified using activated carbon bags in monitoring wells further away from the weir lock. Uranine is adsorbed and accumulated in these bags and therefore this technique does not allow a quantitative assessment. Nevertheless, an advantage is the possibility to detect also very 


\section{Autorenfassung}

Strasser, Montenegro, Blechschmidt, Liesch, Goldscheider: Multi-tracer approach to characterize hydraulically induced sulfate rock dissolution processes below a weir lock, 2016

minor tracer concentrations. The minor Uranine concentration in groundwater is probably caused by the low percentage of surface water and consequently the tracer mass $(0.2 \%)$ as shown before.

Based on these findings, a poor hydraulic connection between most points within the lower aquifer can be assumed. Uranine, like Amidorhodamin G (P18a), was found in the upper and lower aquifers, which can be viewed as definite proof for a hydraulic connection between the two aquifers. Nevertheless, Amidorhodamin $\mathrm{G}$ was only detected in four wells. This fact gives us distinct evidence to characterize the aquifer as a cavern or rather karstic one. The main groundwater flow occurs within just a few preferential flow channels; other hydraulic connectionsapart from these channels are rather poor.

\section{Conclusions}

The interpretation of the results of the described investigations creates a detailed conceptual model of the complex geohydraulic situation of the area surrounding the weir lock Hessigheim. Progressive leaching in the lower aquifer permanently changes hydraulic characteristics of the aquifer and results in strongly heterogeneous geohydraulic conditions. Using the information obtained in the course of the tests, the lower aquifer can be described as a karst system with major flow paths running from north to south and minor ones branching outward. The main runoff occurs over a short distance through channels. A smaller portion of the groundwater volume trickles with lower flow velocities through narrow pathways or through joints in the rock. The results of the tracer tests show that main groundwater flow occurs in the area of the eastern bank below the hydropower plant. The hydrogeochemical investigations illustrate that the sulfate solution processes have already progressed a lot in this area, and thereby channels and cavities have been created. River water infiltrates in both aquifers in the upstream area. Infiltration into the lower aquifer is either through the upper aquifer or directly via joints in cavities. A grout curtain was installed west of the weir lock as part of former physical safeguarding measures. The resulting damming effect and the reversal of the vertical hydraulic gradient prove that this hydraulic barrier is still largely intact and effective. It causes a vertical flow of groundwater from the lower aquifer into the upper aquifer. Therefore, both aquifers interact through hydraulic connections with one another and with the Neckar River. Despite these results, leakage within the upper part of the grout curtain on the western bank cannot be excluded.

\section{Acknowledgements}

The authors thank the Stuttgart office of the Federal Waterways and Shipping Administration for technical and administrative support. We also thank Olivia Wenzel for proofreading the 
Strasser, Montenegro, Blechschmidt, Liesch, Goldscheider: Multi-tracer approach to characterize hydraulically induced sulfate rock dissolution processes below a weir lock. Journal of Applied Water Engineering and Research 20 April 2016 (2016), S. 1-16.

manuscript and supporting us with productive discussions as well as Tim Biedermann and Nils Hoppe for supporting us during numerous fieldwork activities.

\section{Disclosure statement}

No potential conflict of interest was reported by the authors.

\section{Notes on contributors}

Daniel Strasser studied applied geosciences at Tuebingen University where he graduated in 2011. Since then he has been working in the groundwater section at the Federal Waterways Engineering and Research Institute (BAW) in Karlsruhe and as an external PhD student at the hydrogeology division of the Institute of Applied Geosciences (AGW) at KIT. His research is focused on interaction processes of groundwater and surface water.

Héctor Montenegro studied civil engineering at Karlsruhe University where he presented a PhD thesis on inverse parameter estimation for unsaturated flow modeling in 1994. He has been working since 2000 in the groundwater section at the Federal Waterways Engineering and Research Institute (BAW) in Karlsruhe where he is responsible for the geohydraulic analysis around deep excavations for waterways structures.

Lisa Blechschmidt studied applied geosciences at KIT where she specialized in hydrogeology and engineering geology. She did her MSc thesis in cooperation with the Federal Waterways Engineering and Research Institute (BAW) in Karlsruhe and graduated in 2013. Since then she works as a consultant at GHJ Ingenieurgesellschaft $\mathrm{mbH}$ where she focuses on numerical modeling.

Tanja Liesch is a senior lecturer and researcher at the hydrogeology division of the Institute of Applied Geosciences (AGW) at KIT since 2011. She studied geology and geoecology at Karlsruhe University (1999), and completed her $\mathrm{PhD}$ in the field of groundwater protection in 2006. From 2007 to 2009 she worked for a management consultancy in the field of natural disasters management. From 2010 to 2011, she took up a deputy professorship for hydrogeology at the Karlsruhe Institute of Technology (KIT). Her main fields of research include general and applied hydrogeology, groundwater hydraulics, numerical modeling, and groundwater quality and protection. 


\section{Autorenfassung}

Strasser, Montenegro, Blechschmidt, Liesch, Goldscheider: Multi-tracer approach to characterize hydraulically induced sulfate rock dissolution processes below a weir lock, 2016

Nico Goldscheider is professor for hydrogeology at the Institute of Applied Geosciences (AGW) at KIT since 2011. He studied geology and geoecology at Karlsruhe University (1997), completed his $\mathrm{PhD}$ in the field of alpine karst hydrogeology (2002) and worked as senior lecturer and researcher at the Center for Hydrogeology (CHYN) at the University of Neuchâtel, Switzerland, with a focus on karst hydrogeology and tracing techniques (2002-2010). From 2010 to 2011, he was professor for hydrogeology and geothermics at TU Munich, until he accepted the call from KIT.

\section{ORCID}

Daniel Strasser http://orcid.org/0000-0002-9448-8128

Tanja Liesch http://orcid.org/0000-0001-8648-5333

\section{References}

Bethge C. 2013. Grundwasserinduzierte Veränderungen im lösungsempfindlichen Baugrund unterhalb der Schleusenanlage Hessigheim am Neckar [MSc thesis]. Karlsruhe: Karlsruher Institute of Technology, Institute of Applied Geoscience.

Blechschmidt L. 2013. Hydrogeologische Untersuchungen zu den grundwasserinduzierten Veränderungen im lösungsemp findlichen Baugrund im Bereich der Staustufe Hessigheim am Neckar [MSc thesis]. Karlsruhe: Karlsruher Institute of Technology, Institute of Applied Geoscience.

Brunner H, Bloos G, Bruder J, Hinkelbein K, Ulrichs M, Warth M, Wurm F. 1994. Geologische Karte von Baden-Württemberg. Erläuterungen zu Blatt 7021 Marbach am Neckar. Freiburg uns Stuttgart.

Cooper AH.1986. Foundered strata and subsidence resulting from the dissolution of Permian gypsum in the Ripon and Bedale areas. North Yorkshire. In: Harwood GM, Smith DB, editors. The English Zechstein and related topics. London: Geological Society of London, Bd. 22; p. 127-139.

Darcy H. 1856. Les fontaines publiques de la ville de Dijon. Paris: Victor Dalmont.

Dreybrodt W, Romanov D, Gabrovsek F. 2002. Karstification below dam sites: a model of increasing leakage from reservoirs. Environ Geol. 42: 518-524. doi:10.1007/s00254-001- 0514-7

Fick A. 1855. On liquid diffusion. Poggendorffs Annalen 94: 59 


\section{Autorenfassung}

Strasser, Montenegro, Blechschmidt, Liesch, Goldscheider: Multi-tracer approach to characterize hydraulically induced sulfate rock dissolution processes below a weir lock, 2016

Ford D, Williams PW. 2007. Karst hydrogeology and geomorphology. Rev. ed. Chichester (UK): John Wiley \& Sons.

Franzius, L. 1990. Verpressung durch Gipsauslaugung bedingter Hohlräume im Untergrund der Staustufe Hessigheim/ Neckar. Proceedings of Nationale Tagung für Ingenieurgeologie. Karlsruhe, S. 197-213.

Goldscheider N. 2008. A new quantitative interpretation of the long-tail and plateau-like breakthrough curves from tracer tests in the artesian karst aquifer of Stuttgart, Germany. Hydrogeol J. 16: 1311-1317. doi:10.1007/s10040-008- 0307-0

GutiérrezF, Desir G, Gutiérrez M. 2003. Causes of the catastrophic failure of an earth dam built on gypsiferous alluvium and dispersive clays (Altorricón, Huesca Province, NE Spain). Env Geol. 43: 842-851. doi:10.1007/s00254-002-0700-2

Hiller T, Romanov D, Kaufmann G, Epting J, Huggenberger P. 2012. Karstification beneath the Birs weir in Basel/Switzerland: a 3D modeling approach. J Hydrol. 448- 449:181-194. doi:10.1016/j.jhydrol.2012.04.040

Hvorslev MJ. 1951. Time lag and soil permeability in groundwater observations. Vicksburg (MS): Corps of Engineers, U.S. Army (bulletin no. 36).

James AN. 1992. Soluble materials in civil engineering. Ellis Horwood series in civil engineering. Hempstead: Ellis Horwood Ltd.

Jeschke AA. 2002. Lösungskinetik von Gips und Anhydrit [dissertation]. Bremen: University Bremen. Department physics/ electrotechnology.

Käss W. 2004. Geohydrologische Markierungstechnik. Mit 43 Tabellen. 2., überarb. Aufl. Stuttgart: Borntraeger (Lehrbuch der Hydrogeologie, Bd. 9).

Klinchouk A, Andrejchuk V. 1996a. Environmental problems in gypsum karst terrains. Int J Spel. 25:145-156. doi:10.5038/ 1827-806X.25.3.11 Klinchouk A., Andrejchuk V. 1996b. Sulphate rocks as an arena for karst development. Int J Spel. 25:9-20. doi:10.5038/ 1827806X.25.3.1.

Kruseman GP, de Ridder N. 2000. Analysis and evaluation of pumping test data. 2nd ed. completely revised [reprinted 2000]. Wageningen: International Institute for Land Reclamation and Improvement (ILRI publication, 47). 


\section{Autorenfassung}

Strasser, Montenegro, Blechschmidt, Liesch, Goldscheider: Multi-tracer approach to characterize hydraulically induced sulfate rock dissolution processes below a weir lock, 2016

LFU Bayern. 2002. Hinweis für die Durchführung und die Begutachtung von Markierungver-suchen in Gewässern.

Strasser, Montenegro, Blechschmidt, Liesch, Goldscheider: Multi-tracer approach to characterize hydraulically induced sulfate rock dissolution processes below a weir lock. Journal of Applied Water Engineering and Research 20 April 2016 (2016), S. 1-16.

Merkblatt Nr 3 1/2. Stand 06.06.2002. Unter Mitarbeit von Schwarz, Friedmann, Schmederer und Zahn. Bayerisches Landesamt für Wasserwirtschaft. München.

Lienhart DA. 2013. Long-term geological challenges of dam construction in a carbonate terrane. Environ Eng Geosci. 19:1-25. doi:10.2113/gseegeosci.19.1.1.

Mesny M. 2004. Un grand barrage à haut risque. Saddam dam en Irak. La Houille Blanche. 92-96. doi:10.1051/lhb:20040 4014

Milanović PT. 2000. Geological engineering in karst. Dams, reservoirs, grouting groundwater protection, water tapping, tunneling. Belgrade: Zebra.

Pitrak M, Mares S, Kobr M. 2007. A simple borehole dilution technique in measuring horizontal ground water flow. Ground Water. 45:89-92. doi:10.1111/j.1745-6584.2006. 00258.x

Romanov D, Gabrovsek F, Dreybrodt W. 2006. Leakage below dam sites in limestone terrains by enhanced karstification: a modeling approach. Environ Geol. 51:775-779. doi:10. 1007/s00254-006-0394-y

Theis CV. 1935. The relation between the lowering of the piezometric surface and the rate and duration of discharge of a well using groundwater storage. Eos Trans AGU. 16:519-524.

Toride N, Leij FJ, van Genuchten MT. 1993. A comprehensive set of analytical solutions for nonequilibrium solute transport with first-order decay and zero-order production. Water Resour Res. 29: 2167-2182. doi:10.1029/93WR 00496

Trinkw V. 2001. Verordnung über die Qualität von Wasser für den menschlichen Gebrauch. Bundesministerium für Gesundheit; Bundesministerium für Verbraucherschutz, Ernährung und Landwirtschaft. 


\section{Autorenfassung}

Strasser, Montenegro, Blechschmidt, Liesch, Goldscheider: Multi-tracer approach to characterize hydraulically induced sulfate rock dissolution processes below a weir lock, 2016

Wittke W. 1987. Bericht zum Entwurf der Sanierungsmaßnahmen, Staustufe Hessigheim am Neckar. Aachen (Germany): Prof. Dr.-Ing. W. Wittke. Wittke Beratende Ingenieure für Grundbau und Felsbau.

Wittke W. 1998. Bericht zur Untersuchung von Maßnahmen zur Verringerung von Auslaugungen am linken Neckarufer und zur Erarbeitung eines Meßprogramms zur Überwachung der Grundwassersrömung und der Funktionsfähigkeit des Dichtungsschleiers im Bereich d. gesamten Staustufe. Prof. Dr.- Ing. W. Wittke. Wittke Beratende Ingenieure fürGrundbau und Felsbau. Aachen, unpublished. 